\title{
Technology Integration in Improving ESL Learners' Vocabulary: A Systematic Review
}

\section{Nor Azah Sarip@Khalid, Azlina Abdul Aziz}

To Link this Article: http://dx.doi.org/10.6007/IJARBSS/v11-i9/10896

DOI:10.6007/IJARBSS/v11-i9/10896

Received: 12 July 2021, Revised: 14 August 2021, Accepted: 01 September 2021

Published Online: 16 September 2021

In-Text Citation: (Sarip@Khalid \& Aziz, 2021)

To Cite this Article: Sarip@Khalid, N. A., \& Aziz, A. A. (2021). Technology Integration in Improving ESL Learners' Vocabulary: A Systematic Review. International Journal of Academic Research in Business and Social Sciences, 11(9), 1081-1090.

\section{Copyright: (c) 2021 The Author(s)}

Published by Human Resource Management Academic Research Society (www.hrmars.com)

This article is published under the Creative Commons Attribution (CC BY 4.0) license. Anyone may reproduce, distribute, translate and create derivative works of this article (for both commercial and non-commercial purposes), subject to full attribution to the original publication and authors. The full terms of this license may be seen at: http://creativecommons.org/licences/by/4.0/legalcode

Vol. 11, No. 9, 2021, Pg. 1081 - 1090

Full Terms \& Conditions of access and use can be found at http://hrmars.com/index.php/pages/detail/publication-ethics 


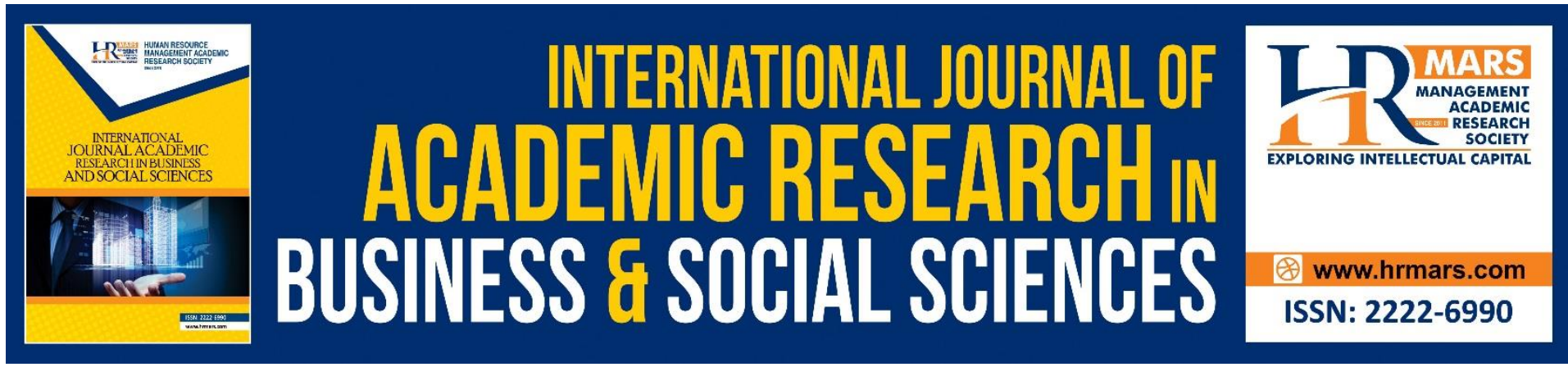

\title{
Technology Integration in Improving ESL Learners' Vocabulary: A Systematic Review
}

\author{
Nor Azah Sarip@Khalid, Azlina Abdul Aziz \\ Faculty of Education, Universiti Kebangsaan Malaysia \\ Email:norazahsarip@gmail.com
}

\begin{abstract}
Integration of technology in explicit instructional strategy vocabularyteaching and learning process become familiar nowadays. This paperproposed a review of current empirical studies on explicit instructional strategy with technology integration and without technology integration in vocabulary teaching and learning to seek the effectiveness of explicit instructional strategy itself and also the effectiveness of technology integration in the strategy. Eighteen past studies reviewed from the online database. Three past studies show that explicit instructional strategy in vocabulary learning assists learners to retain the words successfully and effectively. Meanwhile, with the integration of technology in explicit instructional strategy, vocabulary learning prolongs its effectiveness with added value which makes learners highly motivated and stress - free in order to acquire the vocabulary. The limitations and recommendations for future research also highlighted in this review as a reference to the researchers.
\end{abstract}

\section{Introduction}

One of the utmost and significant elements in learning a second language is learning vocabulary. In order to master all four major skills of language, having broadand rich vocabulary enables them to understand and comprehend the target language (Asyiah,2017: Agustina,2019: Sitompul,2013). Further, Shamiyeva (2018) stresses that it is compulsory to recognize and master vocabulary of the language if someoneis learning the language. For this reason, it's vital to make up and fill in their vocabulary.

The quality of spoken and written form of learners with broad vocabulary is higher than the others with less vocabulary mastery (Rohmatillah,2014). As mentioned by Thornbury (2002) "without grammar very little can be conveyed, without vocabulary nothing can be conveyed". It is a very meaningful phrase, and shows to us how important vocabulary is to language acquisition. If the learners are masters in grammar, yet he or she may not be able to be a good language user if theydo not master the vocabulary. Further, Ur (1996: 60) as cited in Rohmatillah (2014) that it is impracticable to have good communication skills if you have limited wordsespecially when it comes to speaking in second language. Therefore, vocabulary is compulsory to be taught to enhance English language competency. 
Surprisingly, Afzal (2019) mentioned that competency of English language issolely based on vocabulary possessed by the learners including for the native speakeritself. His statement was supported by Yang \& Dai (2012) too, in any language learning it is compulsory to make sure learners acquire the most essential componentwhich is vocabulary. It is merely impossible to acquire the language without masteryof its lexis with extensive reposition in meaning. The word 'vocabulary' itself bringsseveral meanings suggested by the researchers. To Afzal (2019) vocabulary means the words that learners can understand the meaning either they heard or spoke the words meanwhile to Hiebert and Kamil (2005) has a different perspective of vocabulary. They believed that every single word came with two different purposes:oral and print knowledge. Basically, oral knowledge is the words which learners understand and apply for listening and speaking while for print knowledge, learners recognize and use those words for reading and writing.

The Impacts and Challenges of Vocabulary Mastery:

Significantly, learners' achievement is affected by vocabulary mastery. Mukundan et. al (2013) found that most of the students of Form Four who were selected as their respondents only reached the level of "moderate to bad" in writing skill due to less vocabulary acquired. Too bad, many of them also do not have the essential skills on how to describe their own feelings, thoughts and ideas effectivelyin journal writing. Surprisingly it does not happen only for primary and secondary level of students, this problem carries on to the tertiary level of students whereby they face problems in writing formal academic papers due to inadequate vocabulary.

However, most of the learners think that it is not an easy task to master the vocabulary. Rohmatillah (2014) found that most learners have problems with correctspelling in writing, pronouncing the words correctly in spoken language and also confusing in identifying the most compatible that suit with the words and its use in different contexts. She also mentioned that all these difficulties are caused by the differences in written and spoken form in English. They also need to recognize too many words, yet the sources and information about the words are hard to find, somewords are too complicated and most of them get confused on how to pronounce correctly with the words that have the same sounds between English and their first language.

Apart from that, they also cannot remember all the new words they learned. Forgetting always happens and disturbs the process of retaining the words in long term memory (Farjami, \& Aidinlou, 2013). Oxford (1990) as cited in (Farjami \& Aidinlou, 2013) agree that over 100 trillion of new information can be stored in peoples' minds, nevertheless only half of it remains. Forgetting happens when the process of retrieval and excavating the intake of input fails, then the words cannot last in their long-term memory. Additionally, "intra-lexical factors or also known ascross linguistic factors", the degree of the first language of the learnerscomplimenting his or her second language also affect the vocabulary acquisition. Laufer (1997) as cited in Hinkel (2011) found that translation from their mother tongue to the second language may also interrupt the selection of correct words and cause the use of improper words grammatically. 
Further, the awareness regarding the importance of teaching and learning vocabulary also affected the effectiveness of vocabulary mastery. Some teachers might think that learners can learn vocabulary by themselves, do not need the properguidance and can learn naturally from reading activity, perception towards vocabulary is easy and simple to understand. Consequently, it is making them ignore the teaching process while for the learners themselves, they think it's not worth it tostruggle for the vocabulary acquisition process as it's not really high-level intellectual activity. (Coady \& Huckin,1997). Other than that, most learners are also struggling with pronunciation, spelling in different grammatical forms. Learners are not able tochoose the appropriate meaning and use the words in different contexts. They also having problems to recognize words or expression that were idiomatic (Surmanov \&Azimova,2020)

Hence,teaching vocabulary explicitly via technology integration and application ensuring the learners' vocabulary proficiency has been reviewed. The purpose of this systematic review is to discover empirical evidence on the effectiveness of explicit instructional strategy and technology integration in order toimprove ESL learners' vocabulary mastery.

\section{Research Objectives and Research Questions}

This review is conducted to:

- $\quad$ To investigate the effectiveness of explicit instructional strategy in learning vocabulary.

- $\quad$ To investigate the effectiveness of technology integration in explicit instructional strategy in learning vocabulary.

From research objectives mentioned, two research questions discussed:

- How effective is explicit instructional strategy in improving ESL Learners' Vocabulary Mastery?

- How does technology integration help to improve ESL Learners' Vocabulary Mastery?

\section{Literature Review}

\section{Features of Vocabulary Knowledge}

Hornby (1995) as cited in Asyiah (2017) clarify, there were three important elements in vocabulary learning which are words that make up a language, words thatlearners are familiar with or used in communication, reading or writing and also wordsthat learners recognize its meaning. Further, (Thornbury ,2003: Kamil et. al. ,2005) added that vocabulary mastery includes "grammatical behaviour, the word derivation,collocations of the words, connotation or association of the word and word frequency".

On the other hand, Shemiyeva (2018) defined two categories of vocabulary which are oral and print vocabulary. Vocabulary in listening and speaking are knownas oral vocabulary while the other one, print vocabulary used widely in reading and writing. She added that another two categories of knowledge are receptive and productive. The differences between two of them taken as "Receptive" carries the ideathat we receive language in put from others through listening or reading and try to comprehend it. Productive carries the idea that we produce language forms byspeaking and writing to convey messages". Hiebert and Kamil (2005: 3) 
added that learners are familiar with the words and frequently use the words in productive vocabulary while for receptive is vice versa. Yet they still are capable of understanding the words from someones' even though they are faulty.

\section{Role of Vocabulary Acquisition in ESL}

Richards and Renandya (2002) mentioned that the capability in speaking, listening,reading and writing of learners are affected by their vocabulary acquisition. Thus, Asyiah (2017) believed that educators should take attention to the influence ofvocabulary in teaching and learning process in order to enable the students' comprehension and improve their vocabulary mastery. She added that students' language skills including cognitive, affective and behaviour are affected by their vocabulary acquisition. Most students with good vocabulary mastery will also be ableto communicate well as their cognitive's skill relating to how they remember, understand and use the word bloom over time.

In addition, according to Grauberg (1997: 15) as cited in Rohmatillah (2014), the process of learning vocabulary involves four stages. First and foremost is the discrimination which is learners are able to identify sounds and letters eithers next tothem or synonym words while listening,reading,speaking and writing activity take place. Next, learners can identify the meaning of the words, based on its concept. Then, they can remember and store in their memory after knowing the meaning and use appropriately. Last stage is consolidation and extension of meaning.It is acontinuation process of learning, learners may take some time to digest and extend the use of the words. Hiebert and Kamil (2005) agreed, the first stage of the learningprocess may be easy for learners to digest but for the second, third and fourth stages, they need time to grasp the whole semantic knowledge at last.

\section{Vocabulary Teaching and Learning Strategy}

There are two main strategies normally used in teaching and learning English as a second language. Laufer (2003) defined incidental or implicit learning to acquire new words as learners learn the words without any intention of getting to know the words. Theymay listen to dialogue or read the text that consists of the words, then grasp the words in their memory. On the other hand, explicit learning strategy or direct vocabulary learning acquisition is defined as learning that is designed and organized to gain the vocabulary without any other objective of four language skills to focus (Zuo \& Yan, 2019). It affects the effectiveness in words' development and long-term memory retention (Mirzaii, 2012).In other words, explicit learning vocabulary recommended by Thornbury (2002) as it shows greater impact of learners' achievement compared to implicit learning strategy.

The Ministry of Education (MOE) is aware of the scenario and steps taken to enhance vocabulary skills in classrooms. Adding vocabulary learning into syllabus as well as CEFR textbooks for both primary and secondary schools are really an excellent step. Other than that, teachers are also provided with English vocabulary exercises in teachers'modules and students' workbooks to assist them to help their students acquire the list of vocabulary needed. Moreover, Lee et. al. (2019) as cited in Tahir et. al (2020) suggested that teachers nowadays need creativity to approach students engaging with vocabulary learning explicitly. One of them, Sitompul (2013) highlighted that effective learning in teaching and learning vocabulary is using word lists and flashcards. Thornbury (2002) ascited in Sitompul (2013) also states the similar statement that flashcards assist teachers toillustrate to the learners the sequence of simple activity especially for drilling andintroducing new words. Both researchers 
agreed that learners show great improvement after the intervention. Yet using word lists is also useful,less time consuming and economical even though it's a bit monotonous whereby young learners easily lose their attention and get bored. Apart from that, games are always close to young learners. Al Neyadi (2007) mentioned in her study that games effectively boost and enhance young learners' ability to memorize. Surprisingly, games helped learners comprehend the wordsand they were motivated to recognize its meaning. She added they experienced new teaching methods, and enjoyed that much compared to traditional one.

Therefore, teachers and educators have to create something interesting and attractive to meet students' interest, yet meaningful and effective in vocabulary acquisition. Once learners enjoy their lesson and experience an attractive lesson via interactive activity, it stimulates their level of motivation to become higher. Currently, explicit instructional strategy of vocabulary acquisition is as easy as development of varieties of gadget and application in technology that are interesting and user friendly (Wang et. al. ,2015).

Another approach used to acquire vocabulary which proven to lead to effective learning is via computer and smartphone. It also exemplifies via the gadget,learners attained victorious bloom in these students' vocabulary competency from time to time (Wu,2014). Variety of software programs and applications which consist of vocabulary features like meaning in target language, synonym, antonym, spelling, pronunciation andpart of speech are really useful for the learners comprehending the concept (Nakata, 2008).

\section{Method}

The steps taken for this review refer to Kitchenham (2004) which consist of three main phases. For the first phase, planning the review to "identify the need for a review anddevelop the review protocol" that correlated with the effectiveness of explicit instruction vocabulary's teaching and effectiveness of technology instruction in improving the learners' vocabulary mastery. Next, moving on to the second phase which is conducting the review. It is related to discovering and distinguishing past research that is linked to theexplicit instructional teaching of vocabulary and integration in teaching and learning the vocabulary. The selection of suitable and preferable materials being made to further the steps, extract and synthesis the data. Then, the data revised and summary concluded to come with findings. The online bibliography databases used to search for the past relatedarticles, journals or studies on relevant keywords. I used "vocabulary, vocabulary mastery, teaching vocabulary, learning vocabulary, technology, CALL, MALL and explicit instructional strategy" for the searching using Google Scholar, researchgate.net, scholarlyjournals, academia.edu and semantic scholar. The search is only focusing on English articles, journals or studies from 2012 to 2021 . Basically, the chosen article meets the criteria of this following aspect based on its title, abstract, finding and conclusion:

1. The purpose of the studies is to encounter the issues in teaching and learningEnglish as a second language (ESL), specifically in vocabulary.

2. The respondents for the studies either at primary, secondary or tertiarylevels.

3. The research design can be qualitative, quantitative or mix-method design.

4. The intervention areas are based on non- technology integration of explicitvocabulary instruction or technology integration of explicit vocabulary instruction in vocabulary teaching. 


\section{Results and Discussion}

Based on the procedures, 19 articles were shortlisted. Table 1,2 and 3 are the summary of empirical evidence on explicit instructional vocabulary teaching and learning strategies either with technology integration or without technology integration:

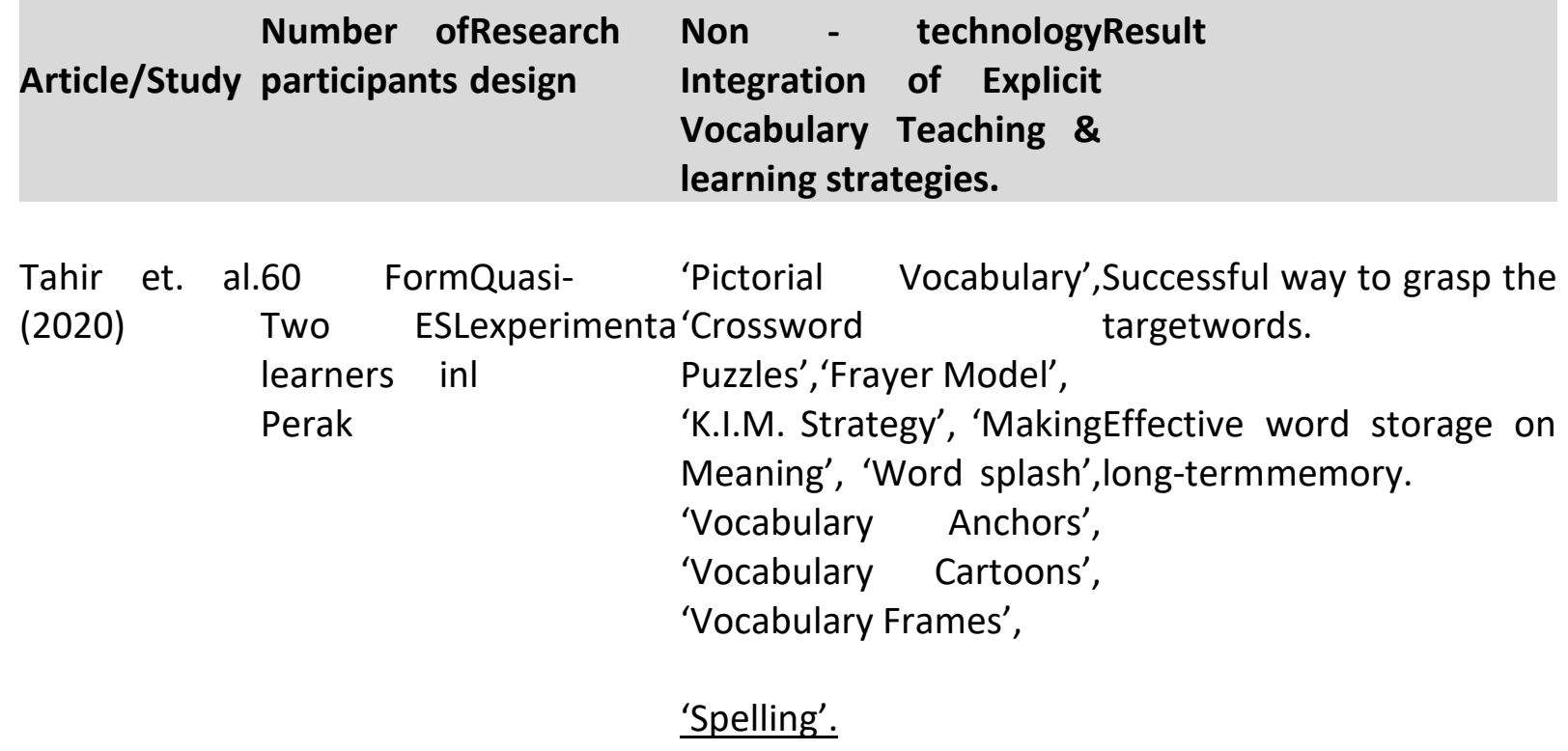

Asyiah(2017) 30 studentsMix methodEmploying a monolingualStudents' choice of from junior(case study) dictionary and wordlists. vocabulary learning high school . Fully-contextual strategies will have some inBandung . De-contextual influences on their Semi-contextual teaching strategy.

Fully contextual was found as the most frequent strategy employed by the teachers through which the teacher teaches the vocabulary directly.

Improve students' Sitompul 60 highQuasi- Using flashcards andvocabulary mastery. Easy to (2013) schools' experimentaword list students in I memorize the words. Motivated to learn.

Indonesia 
Table 1: Summary of studies /articles on non- technology integration of explicit instructional vocabulary teaching and learning approaches.

\begin{tabular}{|c|c|c|}
\hline Article/Study & $\begin{array}{l}\text { Number ofResearch } \\
\text { participants design }\end{array}$ & $\begin{array}{l}\text { Integration of technologyResult } \\
\text { of Explicit Vocabulary } \\
\text { Teaching } \\
\text { and learning approaches }\end{array}$ \\
\hline Cil (2021) & $\begin{array}{l}54 \text { studentsQuasi } \\
\text { of } 5 \text { th gradeexperimental } \\
\text { in a state } \\
\text { school in } \\
\text { Turkey. }\end{array}$ & $\begin{array}{l}\text { Wordwall.net used forWordwall.net was effective } \\
\text { I vocabulary practice withon itsown in enhancing the } \\
\text { games. } \\
\text { students' vocabulary } \\
\text { knowledge. }\end{array}$ \\
\hline
\end{tabular}

Ramos (2021) 30 Grade VIDescriptive Using Digital LearningImproved student's English pupils ofresearch Applications: vocabulary achievement.

Capitol Viewmethod

Christian

Kahoot/Quizizz/Quizlet Increase students' learning

School in motivationand interest.

Santa

Cruz, Laguna.

Agustina (2019) 60 studentsQuasi Use of English video song Quite effective to improve in Futuhexperimental vocabularymastery.

Tuban.

Songs are appropriate to be implemented in the classroom.

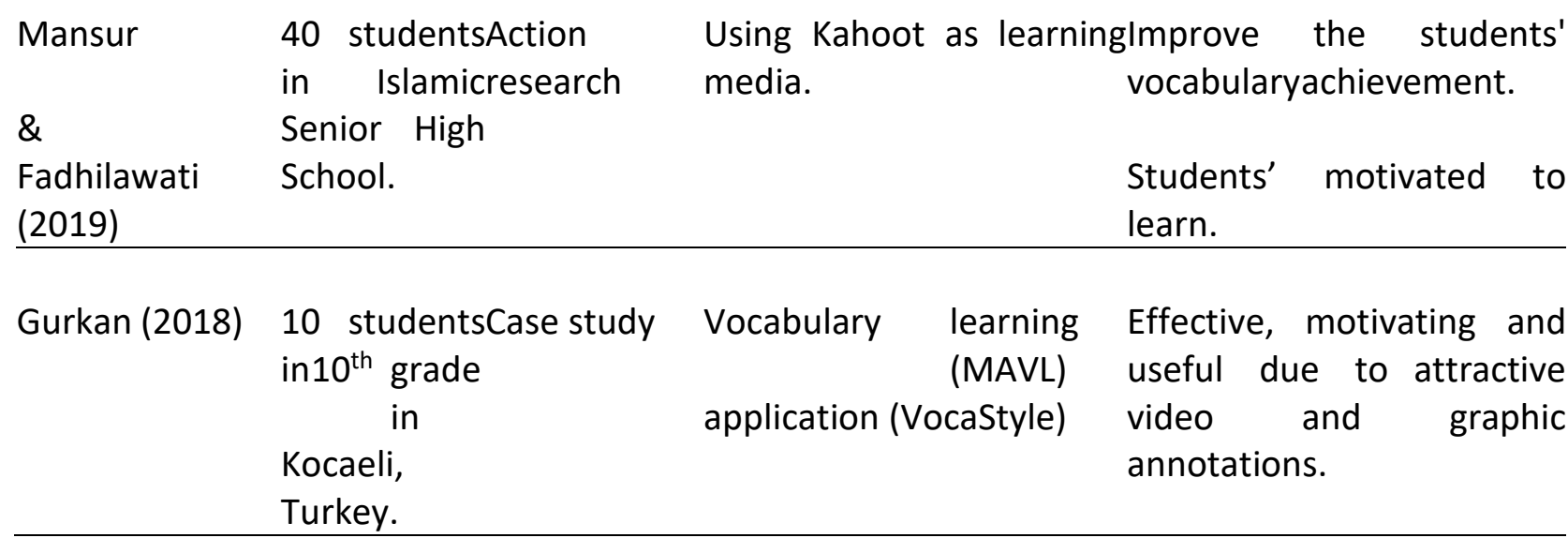




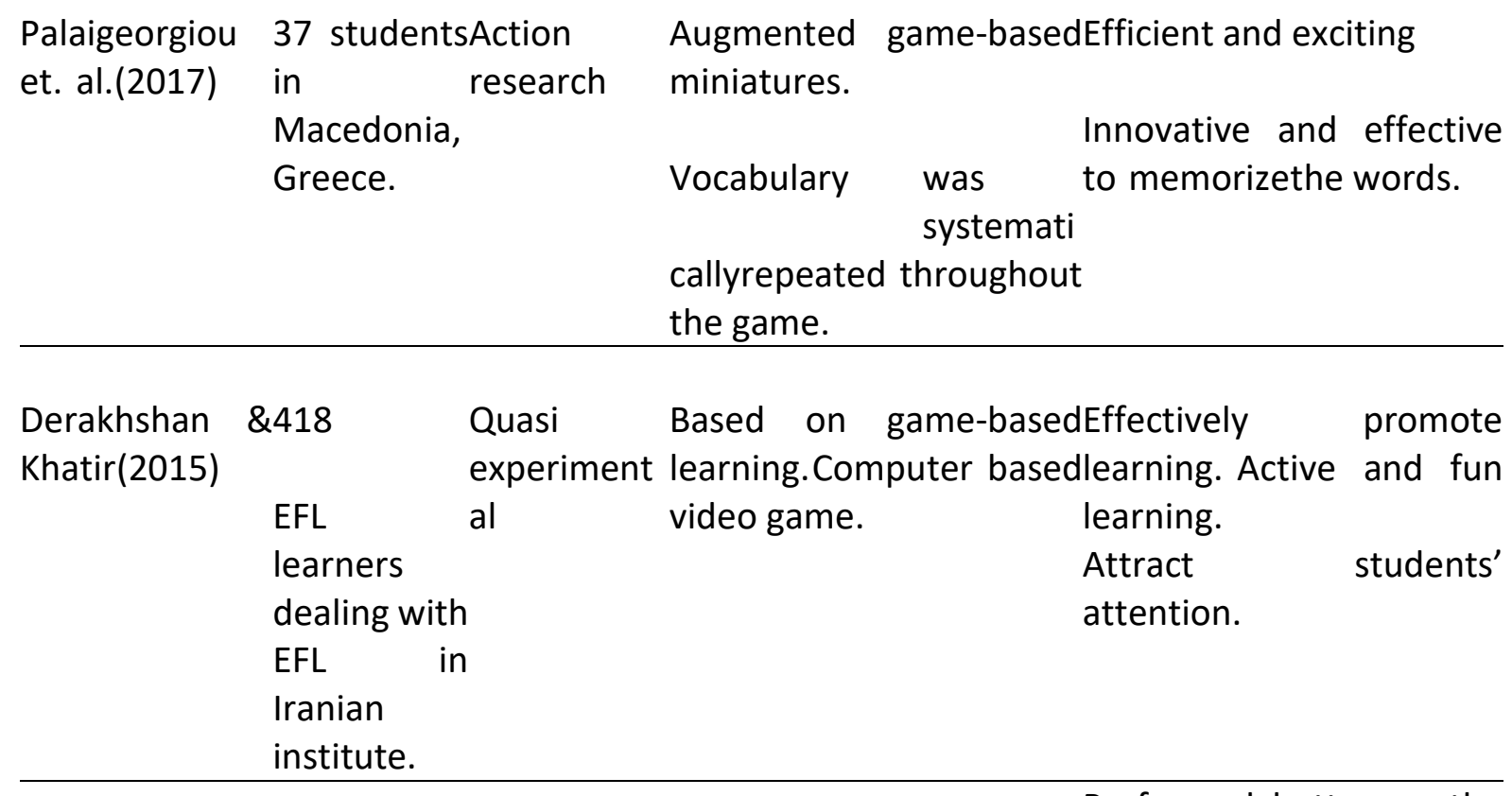

Wang et. al.74 studentsQuasi Use an iPad App namedpost-test. Students' (2015) inTaiwan. experiment "Learn British Englishachievement improved. al Word Power App". Motivation increased.

\begin{tabular}{ll} 
Swondo (2014) 60 studentsQuasi Computer & Vocabularylntrinsic motivation has \\
of secondexperiment Games & highervocabulary mastery \\
semester atal & if they are taught by using \\
the State & Computer Vocabulary \\
University & Games. \\
ofMedan. & \\
\hline
\end{tabular}

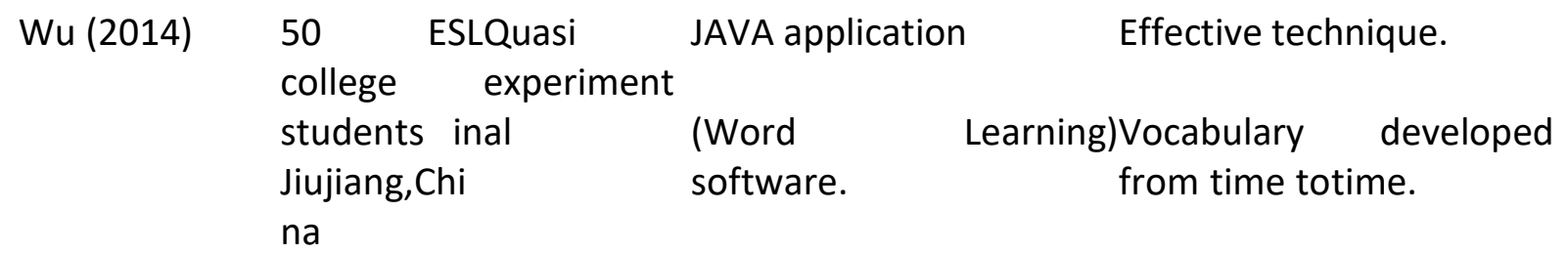

Table 2: Summary of studies /articles on technology integration of explicit instructional vocabulary teaching and learningapproaches. 


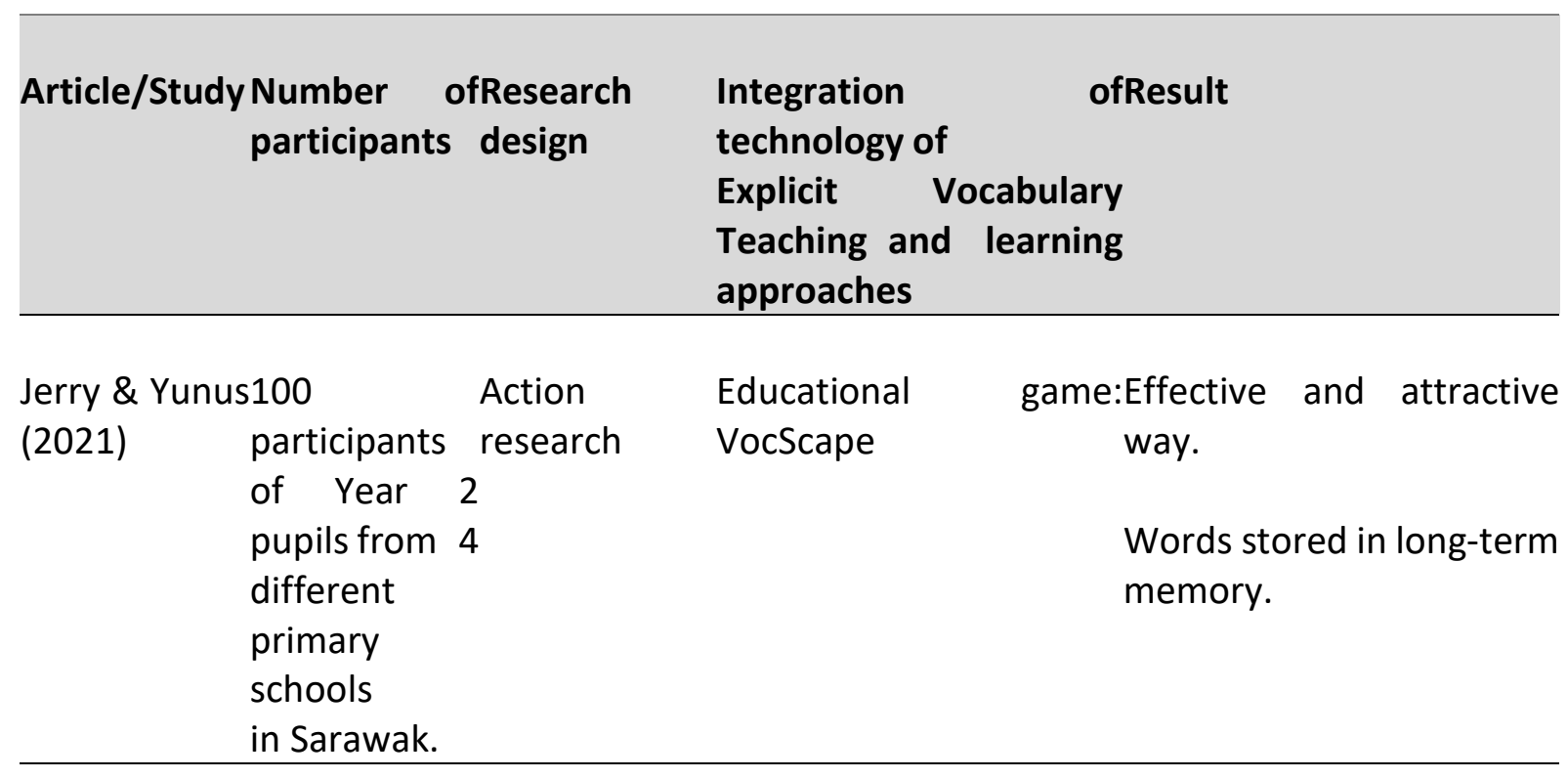

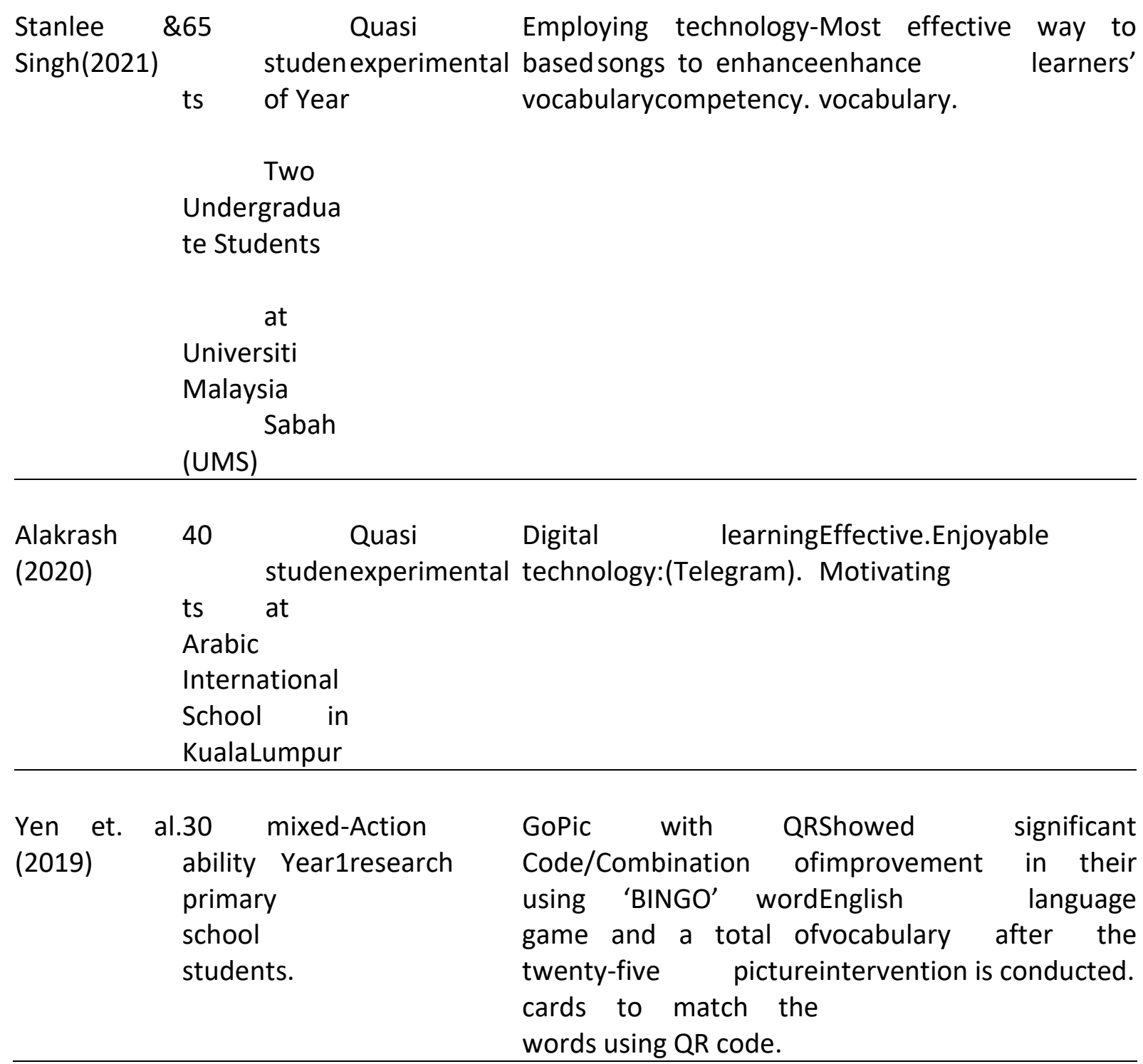




\section{Kassim (2018)60 Quasi Dual Coding Theory andTarget words stored in studen experimental animatedimages. long-termmemory. \\ ts of ESL \\ learners in \\ Terengganu.}

\section{Malaysia ESL Context}

Table 1 showing the summary of non-integration of technology in teaching vocabulary. Three past studies identified the effectiveness of explicit instructional teaching of vocabulary instead of teaching vocabulary implicitly or indirectly. These past studies from5 years back also highlighted the same findings on effectiveness of explicit instruction of vocabulary teaching. This shows that explicit instructional strategy is the best choice to be implemented in teaching vocabulary as the strategy is successful to help learners stored new words, they learnt in their long-term memory (Tahir, 2020). Further, Sitompul (2013) and Aisyah (2017) agreed learners can memorize the words easily, understand and remainmotivated to acquire the words even if it is quite complicated or complex words. However, the explicit instructional without technology integration only shows the effectiveness of learning the content, yet learners' motivation and readiness to learn vocabulary can still be testified.

Therefore, table 2 specifically revised the research or articles which the intervention is focusing on explicit instructional of teaching vocabulary and used technology in their intervention. From 2014 onwards, researchers in China, Taiwan, Iran, Greece, Indonesia and Turkey started looking for technology integration in vocabulary mastery due to the growth of technology in the current situation.

On the other hand, table 3 only shows results for Malaysia ESL context. We can see the development of teaching instruction in Malaysia from 2018 to 2021, the studies indicatedthat teachers and educators are prone to use technology integration in ESL, specifically vocabulary teaching and learning and agree with the effect of using technology application regardless of age and education level, primary, secondary or tertiary. The examples of digitallearning platforms used are Telegram, QR code, Coding and Platform for educational gamingwhich are interactive, show varieties of learning approaches and impactful.

How effective is explicit instructional strategy in improving ESL Learners' Vocabulary Mastery?

From the findings, the effective instructional strategy in improving ESL Learners' Vocabulary Mastery is that vocabulary should be taught explicitly. The outcomes invocabulary learning are more significant to store the words long lasting and recognize the words. As mentioned by Asyiah (2017) one of the main purposes to identify the most appropriate learning strategy related to vocabulary learning is how the strategy can assist thelearners retain the vocabulary they acquired as they can use it later in daily communication or written form. Moir (2002) strengthens the findings with the statement that learners' academic achievements are higher rather than vocabulary taught indirectly, lexical resources of word development are also improved. Additionally, Tahir et. al. (2020) uttered the issues regarding the ability of learners 
to analyze the differences of possible meaning and its contextto use the words. They might not be aware of its spelling too when teachers only integrated the vocabulary learning on an ad hoc basis and only touched it as its surface elements only. Moreover, it affects word choice and wrong usage of vocabulary as learners cannot recognize it's contextual meaning by themselves other than the one stressed by teacher during English lesson if the approaches of teaching implicitly (Darus \& Subramaniam, 2009).

Consequently, explicit instructional strategies involving conscious operation are showing positive impact as highlighted Tahir et. al (2020):Asyiah (2017): Sitompul (2013) :Al Neyadi (2007) in their research. Sitompul (2013) believed that with explicit strategy usedsuch as flashcards and word list, the words that learners gained, they are stress-free and comfortable to memorize and perceive the words easily. For example, of explicit methods which proved to have effectiveness in learning of target words are "Pictorial Vocabulary, Crossword Puzzles, Frayer Model, K.I.M Strategy, Making Meaning, Word Splash, Vocabulary Anchors, Vocabulary Cartoons, vocabulary Frames and Spelling games" (Tahir et. al, 2020). All these activities are fundamentally focused only on vocabulary. Learners arenot disrupted by others' learning objectives such as comprehending the text or understandingthe spoken language if vocabulary indirectly teaches in the teaching and learning process (Mirzaii, 2012). In other words, the learning process should encounter the process of storing the words in their long term memory which is known as unlimited storage. This aim can be achieved via giving more time to learners exposed to the words and letting them explore morewith direct learning activity.

How does technology integration help to improve ESL Learners' Vocabulary Mastery? Moving on to the globalisation era, the teaching and learning process is also developedwith the integration of technology including the vocabulary learning. From 15 past studies mentioned in table 2 and table 3, the significance of technology integration can not be denied.The use of variety of digital tools and digital learning applications such as "Wordwall, Kahoot, Quizizz, Quizlet, English video song, VocaStyle, Game-based learning" usingcomputer game, Word Power App and many more applications as mentioned by those researcher above enhance learners' achievement in terms of vocabulary retention and also motivate them to get engage actively in the lesson. Alakrash (2020) added, learners are enjoyed and stress free in teaching and lesson with the use of technology as tools in vocabulary learning. It is not only attracting young learners but also for adults too as (Derakshan \& Khatir,2015:Wang et. al. ,2015 : Swondo, 2014 : Wu, 2014) found out that tertiary level students are also affected by technology integration in vocabulary learning. They agreed that intrinsic motivation of the students boosts up, their attitude towards learningchanges towards positive development and their performance is better than before theintervention.

As shown in table 3, the ESL teaching and learning process in Malaysia is also following the trend of technology integration. From five years back, researchers highlighted the effectiveness of technology integration as vocabulary teaching explicitly. The educational games such as VocScape mentioned by Jerry \& Yunus (2021) :Yen at. Al. (2019) were effective to help primary learners memory the words easily and stored in their long term memory. Meanwhile the use of digital technology as mentioned by Alakrash (2020) : Stanlee\& Singh (2021) : Kassim (2018) shows that vocabulary learning is easier and more catchy for the learners. They believed that learners enjoyed acquiring more words and were ready to 
explore the words holistically as an explicit instructional strategy used with the integration of technology.

In addition, Gunuc \& Babacan (2018) believes that with technology integration, costand time consuming for one lesson can be reduced, yet boost up the effectiveness of learning the vocabulary with different styles of learning. Surprisingly, with technology integration, learners are also developing their ability to communicate and cooperate with others. They arealso exposed to the self-access learning that can lead to a life-long learning attitude (Wang et. al, 2015). The aim of learning English as a second language which learners are expected to have competency in listening, speaking, reading and writing become a reality due to sufficient and wide vocabulary acquisition with the technology integration (Derakshan et. al.,2015)

\section{Conclusion}

In conclusion, the findings indicated, most influential instructional strategy in vocabulary teaching and learning is explicit method. Most significant effect of researcher'sobservation are vocabulary retention in learner's long-term memory and easiest way to memorize target words (Tahir et. al, 2020: Asyiah, 2017: Sitompul, 2013). One of them, Sitompul (2013) also mentioned regarding to the motivation or readiness of learners to learnnew words.

Added value to this effectiveness of teaching and learning method, technology integration can be adopted to the explicit instructional strategy. Researcher from other countries, (Cil, 2021: Ramos,2021: Agustina, 2019: Mansur \& Fadhilawati, 2019: Gurkan,2018: Palaigeorgiou et. al. ,2017: Derakshan \& Khatir, 2015: Wang et. al.,2015: Swondo,2014: Wu, 2014) proved that most learners performed better after the interventionproceed. They are more excited to learn and enjoy their classroom much. This situation spread over including to our country, Malaysia. ESL teaching and learning related to the vocabulary mastery is currently familiar with technology integration as well. The process of learning involved explicit strategy which boosting up their motivation and well known as an effective tool (Jerry \& Yunus, 2021: Stanlee \& Singh, 2021: Alakrash, 2020: Yen et.al., 2019: Kassim, 2018).

\section{Limitations and Recommendations for Future Researchand Practice}

This review is purposely to provide references for future studies on explicit instructional strategy vocabulary learning with integration of technology. However, it has its own limitationswhile searching for the resources for the review. Some of the journals which are compatible withthe keywords of searching are restricted. Hence, more specific information needed to identify thegaps of journals for the past 10 years. The chosen made need to encounter the quality and meet the inclusive criteria mentioned in the methods. This review also generally focuses on three different stages of learners.

For the future, researchers may only focus past studies in certain groups. For example, researchers may focus on technology integration of explicit instructional vocabulary teaching and learning approaches for primary students only to seek the effectiveness of young learners. 


\section{References}

Afzal, N. (2019). A study on vocabulary-learning problems encountered by BA Englishmajors at the university level of education.

Agustina, N. H. (2019). Using English Video Songs To Improve The Students' Vocabulary Mastery at MTs. Manbail Futuh Tuban (Doctoral dissertation, Uin Sunan Ampel Surabaya).

Alakrash, H. (2020). The Effectiveness Of Employing Telegram Application In Teaching Vocabulary: A Quasi Experimental Study. Alakrash, HM, Razak, NA, \& Bustan, ES (2020). The Effectiveness Of Employing Telegram Application In Teaching Vocabulary: A Quasai Experimental Study. Multicultural Education, 6(1).

Almanar, M. A. (2019). Reviewing Students' Vocabulary Mastery By Using Kahoot At Holmesglen Partnering With University of Muhammadiyah Tangerang. Acitya: Journal of Teaching and Education, 1(2), 78-87.

Al Neyadi, O. S. (2007). The effects of using games to reinforce vocabulary learning. Asyiah, D. N. (2017). The vocabulary teaching and vocabulary learning: Perception,

strategies, and influences on students' vocabulary mastery. Jurnal Bahasa Lingua Scientia, 9(2), 293-318.

Basoglu, E. B., \& Akdemir, O. (2010). A comparison of undergraduate students' English vocabulary learning: Using mobile phones and flash cards. Turkish Online Journal of Educational Technology-TOJET, 9(3), 1-7.

Benkhenafou, H. H. (2015). Memory strategies: boosting vocabulary learning and learner autonomy. International Journal of English and Literature, 5(4), 113-122.

Çil, E. (2021). The Effect of Using Wordwall. net in Increasing Vocabulary Knowledge of5th Grade EFL Students. Language Education and Technology, 1(1), 21-28.

Coady, J., \& Huckin, T. (1997). Second language vocabulary acquisition: A rationale for pedagogy. Cambridge University Press.

Darus, S., \& Subramaniam, K. (2009). Error analysis of the written English essays of secondary school students in Malaysia: A case study. European journal of social sciences, 8(3), 483495.

Derakhshan, A., \& Khatir, E. D. (2015). The effects of using games on English vocabulary learning. Journal of Applied Linguistics and Language Research, 2(3), 39-47.

Derakhshan, A., Salehi, D., \& Rahimzadeh, M. (2015). Computer-assisted language learning (Call): Pedagogical pros and cons. International Journal of English Language and Literature Studies, 4(3), 111-120.

Farjami, F., \& Aidinlou, N. A. (2013). Analysis of the impediments to English vocabulary learning and teaching. International Journal of Language and Linguistics. Special Issue: Language Teaching and Learning Key Principles (LTLKP), 1(4-1), 1-5.

Gunuç, S., \& Babacan, N. (2018). Technology integration in English language teaching and learning. Positioning English for Specific Purposes in an English Language Teaching Context, 1.

Gürkan, S. (2018). The effects of a mobile assisted vocabulary learning application on vocabulary learning. Turkish Online Journal of Qualitative Inquiry, 9(3), 288-311.

Heriyanto, D. (2015). The effectiveness of using YouTube for vocabulary mastery.

ETERNAL (English Teaching Journal), 6(1).

Hiebert, E. H., \& Kamil, M. L. (Eds.). (2005). Teaching and learning vocabulary: Bringingresearch to practice. Routledge. 
Higgins, J. P., Thomas, J., Chandler, J., Cumpston, M., Li, T., Page, M. J., \& Welch, V. A.(Eds.). (2019). Cochrane handbook for systematic reviews of interventions. John Wiley \& Sons.

Hinkel, E. (Ed.). (2011). Handbook of research in second language teaching and learning. Routledge.

Jerry, M., \& Yunus, M. M. (2021). The Use of' Vocscape' in Vocabulary Acquisition Among Year 2 Pupils in Sarawak. Malaysian Journal of Social Sciences and Humanities (MJSSH), 6(4), 308-319.

Kamil, M. L., \& Hiebert, E. H. (2005). Teaching and learning vocabulary. Teaching and learning vocabulary: Bringing research to practice, 1 .

Kassim, W. Z. W. (2018). Utilizing Dual Coding Theory and animated images to enhance ESL students' vocabulary learning. The English Teacher, 47(3), 81-91.

Kitchenham, B. (2004). Procedures for performing systematic reviews. Keele, UK, Keele University, 33(2004), 1-26.

Laufer, B. (2003). Vocabulary acquisition in a second language: Do learners really acquiremost vocabulary by reading? Some empirical evidence. Canadian modern language review, 59(4), 567-587.

Laufer, B. (1990). Ease and difficulty in vocabulary learning: Some teaching implications. Foreign Language Annals, 23(2), 147-155.

Laufer, B. (1997). What's in a word that makes it hard or easy? Intralexical factors affectingthe difficulty of vocabulary acquisition. Vocabulary: Description, acquisition and pedagogy, 140-155.

Lewis, M. (1993). The lexical approach (Vol. 1, p. 993). Hove: Language teachingpublications. Maharaj, A. A. (2017). Speeding up vocabulary acquisition through action research. International Journal of Applied Linguistics and English Literature, 6(4), 245-254.

Mansur, M., \& Fadhilawati, D. (2019). Applying Kahoot to improve the Senior High School students' vocabulary achievement. VELES Voices of English Language Education Society, 3(2), 164-173.

Mirzaii, M. (2012). Implicit vs. explicit vocabulary learning: Which approach serves long-term recall better?. 3L: Language, Linguistics, Literature ${ }^{\circledR}, 18(2)$.

Moir, J., \& Nation, I. S. (2002). Learners' use of strategies for effective vocabulary learning. Mukundan, J., Mahvelati, E. H., Din, M. A., \& Nimechisalem, V. (2013). Malaysian secondary school students $=E S L$ writing performance in an intensive English

program. World Applied Sciences Journal, 22(12), 1677-1684.

Nakata, T. (2008). English vocabulary learning with word lists, word cards and computers: Implications from cognitive psychology research for optimal spaced learning. ReCALL: the Journal of EUROCALL, 20(1), 3.

Ramos, A. G. L. (2021). Enhancing English Vocabulary Through Digital LearningApplications. EPRA International Journal of Research \& Development, 6(6), 40-45.

Richards, J. C., Richards, J. C., \& Renandya, W. A. (Eds.). (2002). Methodology in language teaching: An anthology of current practice. Cambridge university press.

Rohmatillah, R. (2014). A Study On Students Difficulties In Learning Vocabulary. English Education: Jurnal Tadris Bahasa Inggris, 6(1), 75-93.

Shamiyeva, R. (2018). Strategies for teaching vocabulary. In International Scientific and Practical Conference World science (Vol. 5, No. 5, pp. 41-43). ROST.

Sheridan, R., \& Markslag, L. (2017). Effective Strategies for Teaching Vocabulary: An Introduction to Engaging Cooperative Vocabulary Card Activities. PASAA: Journal of Language Teaching and Learning in Thailand, 53, 214-229. 
Sitompul, E. Y. (2013). Teaching vocabulary using flashcards and word list. Journal of English and Education, 1(1), 52-58.

Stanlee, T. J., \& Singh, S. S. B. (2021). Effectiveness of Using Technology Based Songs toEnhance Vocabulary Competency among Year Two Undergraduate Students at Universiti Malaysia Sabah (UMS): Keberkesanan Penggunaan Lagu Berasaskan Teknologi Untuk Meningkatkan Kecekapan Perbendaharaan Kata di Kalangan Pelajar Tahun Dua di Universiti Malaysia Sabah (UMS). Sains Insani, 6(1), 162-166. Surmanov, S., \& Azimova, M. (2020). Analysis Of Difficulties In Vocabulary Acquisition.

The Journal of Legal Studies, 6(1), 144-153.

Sung, Y. T., Chang, K. E., \& Liu, T. C. (2016). The effects of integrating mobile devices with teaching and learning on students' learning performance: A meta-analysis and research synthesis. Computers \& Education, 94, 252-275.

Sutrisna, G. (2021). Vocabulary Acquisition in EFL: A Literature Review of Innovative Vocabulary Teaching Strategies. Yavana Bhasha: Journal of English LanguageEducation, 4(1), 8-17.

Swondo, A. P. (2014). The Effect Of Games and Motivation On Students' Vocabulary Mastery (Doctoral dissertation, UNIMED).

Tahir, M. H. M., Albakri, I. S. M. A., Adnan, A. H. M., \& Abd Karim, R. (2020). The Effects of Explicit Vocabulary Instructions on Secondary ESL Students' VocabularyLearning. $3 L$ : Language, Linguistics, Literature ${ }^{\circledR}, 26(2)$.

Teng, F. (2015). Assessing the Relationship between Vocabulary Learning Strategy Use and Vocabulary Knowledge. PASAA: Journal of Language Teaching and Learning inThailand, 49, 39-65.

Thornbury, Scout. (2002). How to Teach Vocabulary. London : Longman.

Thornbury, S. (2003). Teaching vocabulary using short texts. Asian EFL J, 5(2), 230-234.

Veeramuthu, V., Veerappan, L., Suan, W. A., \& Sulaiman, T. (2011). The effect of scaffolding technique in journal writing among second language learners. Journal of Language Teaching and Research, 2(4), 934-940.

Wang, A. I., \& Tahir, R. (2020). The effect of using Kahoot! for learning-A literature review. Computers \& Education, 149, 103818.

Wang, B. T., Teng, C. W., \& Chen, H. T. (2015). Using iPad to facilitate English vocabulary learning. International Journal of Information and Education Technology, 5(2), 100-104.

$\mathrm{Wu}, \mathrm{Q}$. (2014). Learning ESL vocabulary with smartphones. Procedia-Social and Behavioral Sciences, 143, 302-307.

Xalmurzayevna, Y. S., Karimovich, S. S., Zairjanovich, Y. S., \& Qizi, X. M. I. (2021, June). The Effectiveness Of Quizlet Application Towards Students' Motivation In Learning Vocabulary. In Archive of Conferences (Vol. 26, No. 1, pp. 16-18).

Yang, W. D., \& Dai, W. P. (2012). Vocabulary Memorizing Strategies by Chinese University Students. International Education Studies, 5(1), 208-214.

Yen, E. L. Y., Khair, A. H. M., Yusof, N. M., \& Yunus, M. M. (2019).GoPic with QR Codefor Vocabulary Mastery.

Zain, D. S. M., \& Bowles, F. A. Mobile-Assisted Language Learning (MALL) for Higher Education Instructional Practices in EFL/ESL Contexts: A Recent Review of Literature.

Zuo, F., \& Yan, X. (2019). Incidental English Vocabulary Acquisition through Reading: AReview in the Last Two Decades. English Language Teaching, 12(12), 39-45. 